University of Chicago Law School

Chicago Unbound

Journal Articles

Faculty Scholarship

1992

\title{
International News Service v. Associated Press: Custom and Law as Sources of Property Rights in News
}

Richard A. Epstein

Follow this and additional works at: https://chicagounbound.uchicago.edu/journal_articles

Part of the Law Commons

\section{Recommended Citation}

Richard A. Epstein, "International News Service v. Associated Press: Custom and Law as Sources of Property Rights in News," 78 Virginia Law Review 85 (1992).

This Article is brought to you for free and open access by the Faculty Scholarship at Chicago Unbound. It has been accepted for inclusion in Journal Articles by an authorized administrator of Chicago Unbound. For more information, please contact unbound@law.uchicago.edu. 


\title{
INTERNATIONAL NEWS SERVICE V. ASSOCIATED PRESS: CUSTOM AND LAW AS SOURCES OF PROPERTY RIGHTS IN NEWS
}

\author{
Richard A. Epstein
}

\section{The Origins of Property Rights}

$7 \mathrm{HE}$ origin of property rights has long been a source of contro1 versy both within the law and beyond it. On the one hand there are those who see the source of property rights in the positive law. In line with the theories of John Austin, ${ }^{1}$ law is regarded as a command of the sovereign, and knowledge of property rights derives from understanding what the sovereign, through his courts, has decreed to be recognized and protected as property rights. ${ }^{2}$

In opposition to Austin stands an alternative view that grounds property rights on the traditions and common practices within a given community. ${ }^{3}$ On this view, property comes froin the bottom up, and not from the top down. In other words, the state does not hand down the law or create property rights, any more than it decrees the laws of physics or chemistry. Its chief function is to discover and reflect accurately what the community has custornarily regarded as binding social rules and then to enforce those rules in specific controversies. The image in this context is not of courts-or even legislatures-that "inake" the law, but rather of courts and legislatures that "find" and respect the law, which they then refine by incremental changes and marginal decisions.

One reason why the controversy between these two positions is so hard to resolve is that each has advantages over the other. Rehance

* James Parker Hall Distinguished Service Professor of Law, University of Chicago. I would like to thank Douglas Baird and William Landes for their insightful comments on an earher draft of this Article.

1 See John Austin, The Province of Jurisprudence Determined (1832), reprinted in The Province of Jurisprudence 5-6 (Legal Classics Libr. ed. 1984).

2 See, e.g., H.L.A. Hart, The Concept of Law 20-25 (1961); Thomas Hobbes, Leviathan 312 (C.B. MacPherson ed., Penguin Books 1968) (1651).

3 Sce Robert C. Ellickson, Order Without Law: How Neighbors Settle Disputes 254 (1991); Richard A. Epstein, The Path to The T.J. Hooper: The Theory and History of Custom in the Law of Torts, 21 J. Legal Stud. 3 (1992). 
upon customary practices reduces many of the problems of knowledge for the legal system. Once custom is accepted as controlling, it is no longer necessary for judges to guess what set of rules best accommodate the communities they serve. That information is generated by trial and error from below, and those practices that survive have good claim to being beneficial (one could almost say efficient or wealthmaximizing) for the community at large. If, for example, one wants to figure out the optimal ownership rules over whales, it is unnecessary to resort to abstract primciples of legal title or social justice. One can simply observe the multiphicity of practices im different whalmg environments, each appropriate for its different kind of whale. ${ }^{4}$ In some instances, there may be a single owner of the whale, and im others, ownership of the whale may be divided. So long as the separate sphere of application for each rule is well-delineated, there is no reason to formulate a single uniform rule to cover all takers.

In addition, custom provides an effective bulwark agamst bias and corruption. The custom is the result of repeated imteractions, trial and error, and incremental modifications, and is formed by persons who are, of necessity, ignorant of the position they will occupy in any future dispute. All persons who gain from the use of the custom generally may lose from its application in a particular case. Therefore, when a dispute arises, the custom effectively binds the higants, who now have every incentive to deviate from it. Judges no longer have the ability or the need to make freewheeling judgments about the practices of industries with which they have scant connection, although they must always be alert to the reach and the limit of the customs they apply.

4 Oliver Wendell Holmes, Jr. described the divergent whaling rules as follows:

In the Greenland whale-fishery, by the English custom, if the first striker lost his hold on the fish, and it was then killed by another, the first had no claim; but he had the whole if he kept fast to the whale until it was struck by the other, although it then broke from the first harpoon. By the custom in the Gallipagos, on the other hand, the first striker had half the whale, although control of the line was lost. Each of these customs has been sustained and acted on by the Englisli courts, and Judge Lowell has decided in accordance with still a third, which gives the whale to the vessel whose iron first remains in it, provided claim be made before cutting in.

Oliver W. Holmes, Jr., The Common Law (1881), reprinted in The Common Law \& Other Writings 212 (Legal Classics Libr. ed. 1982) (footnote oinitted). These customs were not the outgrowth of judicial decisions. See Ellickson, supra note 3, at 192. 
Customary rules also may be attacked. One obvious limitation, accepted even by defenders of customary standards, is that they do not bind strangers. For example, a custom of factory owners to pollute farms may adjust relations between factory owners, but it surely cannot bimd farmers. Similarly, a custom of slavery does not bind the slaves. But even within a closed community, customary rules may be criticized, as they were by Justice Joseph Story, on the ground that they do not have the regularity, uniformity, or predictability their supporters clann. As Justice Story, sitting as Circuit Justice for the United States Court of Appeals for the First Circuit, wrote in The Reeside: ${ }^{5}$

I own myself no friend to the almost indiscriminate habit of late years, of setting up particular usages or customs in almost all kinds of business and trade, to control, vary, or annul the general habilities of parties under the common law, as well as under the commercial law. It has long appeared to me, that there is no small danger in admitting such loose and inconclusive usages and customs, often unknown to particular parties, and always liable to great misunderstandings and misinterpretations and abuses, to outweigh the well-known and wellsettled principles of law.

The implication of Story's observation is that the positive law provides a clear rule of law with a umiversal frame of application. Although (in fairness) Story's renuarks were made in the context of a case in which a party to a contract sought to use custons to override the unambiguous "positive" term of the contract, Story's dictum was understood to cover not only the commercial law, but the general principles of the common law as well, where it has received (again im connection with the whaling trade) a frosty reception. ${ }^{6}$

The tradeoff between these two positions shonld be evident. The positive law is defended on the grounds of its administrative ease of apphication, the custoniary law on its suitability to the particular con-

520 F. Cas. 458,459 (C.C.D. Mass. 1837) (No. 11,657).

6 See Swift v. Gifford, 23 F. Cas. 558, 559 (D. Mass. 1872) (No. 13,696), observing that

[t] he whale fishery is the only branch of industry of any importance in which it [custom] is likely to be much used; and if a usage is found to prevail generally in that business, it will not be open to the objection that it is likely to disturb the general understanding of mankind by the interposition of an arbitrary exception.

Note that Story clearly is correct when he notes that explicit terms of a contract take precedence over an imdustry custom, for custom is best understood as setting out the "right" default provisions, not as creating a body of inandatory terms. 
text in which it arises. There is no necessary truth that says that the one feature should dominate the other, and it is quite possible to find contexts in which the custorn does (or should) prevail and others in which quite the opposite prevails.

Most people have hittle difficulty in understanding how the legal system works when law functions as a command. The cominand issues forth from the state, which has a inonopoly on the lawful use of force within the state. Comphance, therefore, is required of all individuals and is secured, in turn, by administrative and legal personnel working in strict hierarchical order.

The origin of custom, however, is a greater inystery. In this context, the central question arises: How can any social system achieve through evolution a spontaneous order that offers the stability necessary for a systein of property rights to thrive? The process of spontaneous evolution is, at root, regarded as a benevolent collective process, even though it lacks a system of central coordination and control. Legal recognition of the rule is not a conscious act of innovation by the judge who first voices it on the legal record. Rather, the judicial decision, and the reasoning that underhes it, offers only an outside observer's account of a preexisting set of social understandings whose validity is asserted and defended ouly when it becomes the subject of special attack in the courts.

Indeed, at soine level, the process is even more general. Countless societies have developed over the centuries coinplex systems of property rights to govern all sorts of resources and situations. In inost of these cases, the property rights that einerged were not the result of any conscious effort on the part of a central planning agency to delineate the relevant rights. Indeed, in many cases it looks as though the property rights that einerged within a given community were both created and maintained by a form of custoin that received, in inchoate form, the general approbation and approval of all the parties within the group. The results of this process of custoinary accretion and developinent have largely been beneficial to the societies that have adopted them, sometnnes even better than the elaborate systenis of property rights that central planners have created. It is possible to be excessive in the celebration of the evolution of the common law of customary property rights, but there is a good deal to be said for the 
process of "spontaneous order," as first foreshadowed by David Hume $^{7}$ and as ultimately championed by Friedrich Hayek. ${ }^{8}$

Yet there are some puzzling features to this account. The very decentralization of the process suggests that the property rights that develop in such a system, if any, should become prey to the process of destruction whenever any single player defects from the rules of the game as it is normally played. For once one party deviates from the custoinary rule of behavior, playing by the rules yields a lower rate of return for other persons who stay within the system, who then have a greater incentive to defect from the system. As one player can foresee that others will defect, the temptation to obtain the gams of the first defector should be very great, so that someone will leave first, leaving all the more reason for others quickly to follow suit. Of course, once the rights become partial or fragmentary, they cease to be property rights, at least in the sense of rights good against the rest of the world, though the notion of rights good agamst the rest of the world is itself subject to important qualification. ${ }^{9}$ The corrosive logic of the prisoners' dilemma game appears to imply the absence of stable custoinary regimes, whether in the area of water rights or hunting territories. ${ }^{10}$

Nonetheless, we encounter systems of property rights that do, in fact, endure and are understood even before the courts becoine imvolved in the process of their delineation and protection, although admittedly the phenomenon need not be a universal one. In essence, the puzzle that has to be solved is not why $A$ or $B$ defects first, but how custom survives long enough for a stable rule to einerge from which any defections are possible at all. In this Article, I shall look at one system of property rights whose contours are very difficult to understand and evaluate-the system of property rights in "news."

7 See III David Hume, A Treatise of Human Nature 407 (L.A. Selby-Bigge ed., 1965) (1888).

8 See Friedrich A. Hayek, New Studies in Philosophy, Politics, Economics and the History of Ideas (1978); Friedrich A. Hayek, Law, Legislation and Liberty (1973). See generally John Gray, Hayek On Liberty 31-33 (2d ed. 1986) (exploring the relationship between Hayek's idea of spontaneous order and the Darwinian notion of natural selection). In essence, Hayek sees a powerful role for custonary forces that he between pure instinct on the one hand and centralized planning on the other. See id. at 29. The conneetion between Hume and Hayek is duly noted by Gray. Id. at 31 .

9 See infra text accompanying notes 71-82.

10 See Carol Rose, The Comedy of the Commons: Custom, Commerce, and Inherently Public Property, 53 U. Chi. L. Rev. 711 (1986). 
The central case is, of course, the justly celebrated decision of the United States Supreme Court in International News Service v. Associated Press ${ }^{11}$ ("INS"). The discussion calls for an inquiry imto both the particular circumstances of the case and the more general system of property rights surrounding it.

In Part II, I look at the case as dealing with the origins of property rights in custom and common practice. In Part III, I examine the case in hight of the general principles of property at common law, namely those that give property to whomever takes first possession of a thing, and ask how, if at all, these principles carry over into the field of property rights in information, especially news. The final Part then offers some more general remarks about the dual aspect of property rights and the tensions that they create for any legal system.

\section{INS AS CUSTOM}

\section{A. The INS Case-in Context}

For the purposes of this Article, it is useful first to state the traditional account of the facts. ${ }^{12}$ The Associated Press ("AP") was incorporated under New York law in 1900. It had about 950 members who were bound by an elaborate set of contractual understandings with each other. The central mission of the AP was to collect news from around the world and to distribute that news in timely fashion to each of its member papers. Under its imternal rules, the AP transferred to each of its members news reports for publication, language and location specified in the certificate of membership. The bylaws of the orgamization specified that no inember newspaper, nor any of its employees, was allowed to transfer the news reports or the information contained therem to any person or organization not a member of the organization. In addition, the bylaws required each member newspaper to collect news from its region and transmit it to the AP for use by all of its menibers. Altliough later imvalidated in part on antitrust grounds, ${ }^{13}$ the AP's bylaws allowed old members unilaterally to bar their competitors from AP membership unless overruled

11248 U.S. 215 (1918).

12 For more detailed accounts of the business structures of both firms, see id. at 229-31; Associated Press v. International News Serv., 240 F. 983, 984-85 (S.D.N.Y.), modified, 245 F. 244 (2d Cir. 1917), aff'd, 248 U.S. 215 (1918) (“Associated Press P”).

13 See Associated Press v. United States, 326 U.S. 1 (1945). 
by a vote of four-fifths of the membership. ${ }^{14}$ During the year 1915, the AP spent $\$ 3,500,000$ for the collection of news.

The International News Service ("INS") was organized as a stock corporation under New Jersey law in 1909. The Hearst Newspapers dominated the INS. The INS was about half the size of the AP, with a membership roster of about 400 newspapers and an annual expenditure on news of around $\$ 2,000,000$ during 1915. Notwithstanding the difference in corporate structure from the AP, the INS also gathered news and information that it then sold to its customers and chents.

For both organizations, the rules regarding the collection and dissemination of news were drafted with the exphicit knowledge that the value of the news to the members depended upon their exclusive ability to get it to their respective markets as quickly as possible. It was clear that the two organizations were in keen competition with each other in the collection and distribution of their stories, as were many of the papers that subscribed to the two services. There was minimal overlap in the membership of the two groups.

When the case was in the lower courts, two business practices of the INS were im issue. First, im order to obtain some information from AP sources, the INS had bribed employees of the newspapers in the AP circle to provide the INS with copies of the stories before they were printed, thereby imducing AP member newspapers to violate their internal bylaws. Second, the INS had taken AP stories as they appeared on bulletin boards and in the early eastern editions of AP papers and had fed those stories verbatim to INS papers. In so doing, the INS did not acknowledge the source of its own information, but by the same token, it did not exphcitly claim that it had produced the news stories. It just treated them as stories collected in the ordimary course of its business, leaving it to its member papers and readers to draw an inference from the silence, if they cared to think about the point at all, that the INS had, in fact, collected these stories in the ordinary course of its business.

It appears that this last set of practices was precipitated by a controversy that arose when the INS (controlled by the Hearst papers)

14 Id. at 10; see also INS, 248 U.S. at 264 n.1 (1918) (Brandeis, J., dissenting) (describing, in general terms, provisions of AP bylaws pertaining to admittance of new ineinbers). In contrast, newspapers that did not coinpete with AP members could be admitted by simple vote of the board of directors. Associated Press, 326 U.S. at 9. 
had taken positions that were strongly sympathetic to the German cause in the First World War. In retaliation, the British and French authorities cut INS personnel off from the front lines and barred them from using the entire European cable system. ${ }^{15}$ The upshot was that the INS could not readily supply stories about the war in Europe to its subscribers within the demanding time constraints of the news business. In some cases at least, the INS had used AP sources for its own stories, and the AP complaint alleged that the practice was a consistent and ongoing one. ${ }^{16}$

During the course of the litigation below, the Umited States District Court for the Southern District of New York enjoined the bribes and the inducement. ${ }^{17}$ Altliougl1 it thought that using AP stories verbatim without attribution constituted an unfair trade practice, it refused to enjoin the practice, given that the case was one of "first impression." 18 The United States Court of Appeals for the Second Circuit affirmed the District Court's first two loldings but reversed the denial of the mjunction against verbatim use without attribution. ${ }^{19}$ The Supreine Court, speaking througli Justice Mahlon Pitney, affirmed im an elaborate opimon, recognizimg the "quasi-property" interest that the AP had in its news stories while they were still "fresh," at least against its direct competitor, the INS. ${ }^{20}$

15 According to the testimony in the case:

[O]n October 10,1916, the International News Service was forbidden by an Act of the British Government from securing any news in Great Britain, or from using any of the cable lines running from Great Britain. On November 8, 1916, a like prohibition was established in France. [Similar prohibitions were imposed in Canada, Japan and Portugal.] Froin and after these dates it was not possible for the International News Service to obtain or receive news by telegraph or cable from any of the countries indicated, and yet day by day it has regularly sent out news to its clients as if received from these countries by the cables connecting them with the United States.

Deposition of Melville E. Stone at 24, INS (No. 221); see also INS, 248 U.S. at 263 (Brandeis, J., dissenting) (describing the same). Justice Louis Brandeis treated the point as an allegation, see id., but the district court found that "the Allies have deprived the defendant of the right to use their cables, and thus get news readily in the countries of Europe." Associated Press I, 240 F. at 986-87.

16 Complaint of the Associated Press at 14-15, INS (No. 221).

17 Associated Press $I, 240$ F. at 987-90.

18 Id. at 996.

19 Associated Press v. International News Serv., 245 F. 244 (2d Cir. 1917), aff'd, 248 U.S. 215 (1918) ("Associated Press IP").

20 INS, 248 U.S. at 215. In my view, Justice Pitney is the most underrated justice in the history of the Court. It is worth mentioning just a couple of the important decisions that he wrote: Eisner v. Macomber, 252 U.S. 189 (1920) (holding that gain realized from common 
In many ways, the decision is quite extraordinary. One can search the length and breadth of Pitney's opinion for some mention of the special circumstances that led the INS to "steal" ("misappropriate" is the polite word) the stories that the AP liad prepared at its own expense. Only Justice Louis Brandeis refers to these facts, and then toward the end of his opinion. His purpose, moreover, is not to explain their relevance to a theory of custoinary rights, but to justify his broader conclusion that legislatures, and not courts, should take the lead in creating property rights in news. ${ }^{21}$ Yet that change in external circumstances is critical both to the narrative behind the case and to its proper legal analysis: Barring one news service from the front will lead to the creation of a inonopoly when its coinpetitors are allowed continued access to the front. More concretely, neither Pitney, Oliver Wendell Holmes in his undistinguislied partial concurrence, nor Brandeis in dissent inquire about a raft of issues that are critical for understanding the broader institutional context of the case. Let ine note soine of them liere:

(1) Although the INS misappropriated AP stories from the bulletin boards and early newspapers in this case, did it ever do so on any otlier occasion or for any otler reason? The point bears special recounting because it was evident that these two titans of the news world had been in coinpetition with each other for several years before the INS pirating actually took place. ${ }^{22}$ At all times, then, the

stock dividends must be recognized at the time of disposition, not the time of receipt, of the stock); Hitchman Coal \& Coke Co. v. Mitchell, 245 U.S. 229 (1917) (upholding inducement of breach of contract claims against unions); Coppage v. Kansas, 236 U.S. 1 (1915) (striking down collective bargaining on the railroads). For these purposes, the question is not whether one agrees with Pitney, as I tend to do. It is that he clearly battles both Holmes and Brandeis as their intellectual equal, as is surely the case in INS.

21 Justice Brandeis described the INS's predicament as follows:

A large majority of the newspapers and perhaps half the newspaper readers of the Umited States are dependent for their news of general imterest upon agencies other than the Associated Press. The channel through which about 400 of these papers received, as the plaintiff alleges, "a large amount of news relating to the European war of the greatest importance and of inteuse interest to the newspaper reading public" was suddenly closed. The closing to the Intcrnational News Service of these channels for foreign news (if they were closed) was due not to unwillingness on its part to pay the cost of collecting the news, but to the prohibitions imposed by foreign governments upon its securing news from their respective countries and from using cable or telegraph lines running therefrom.

INS, 248 U.S. at 263 (Brandeis, J., dissenting).

22. See Complaint of the Associated Press at 12, INS (No. 221). 
INS had the opportunity to take information from AP bulletin boards or from the early editions of AP member papers. Did it do so? Why?

(2) When the INS did misappropriate stories from the AP's bulletin boards and the early editions, did it do so only for the stories pertaining to the events in the European theater from which it had been barred? For all other stories, did the INS continue to rely upon the information that it had gathered by its own labor, without misappropriating AP stories or sources? Note that it was no more difficult for the INS to take these other stories than it was for it to take the stories that related to the front.

(3) Did the AP at any time take INS stories? It doubtless had ample opportunities to do so, given that the INS employed roughly the same technology, and it might even have regarded retaliation agamst the INS as a desirable form of self-help. If the AP did not take INS stories, why did the AP, in an area of law that was uncharted and full of pitfalls, decide to seek an mjunction in court, one which sought to analogize the misappropriation of the news stories to the bribery and inducement counts in the case?

(4) Were there any new entrants into the news busmess that sought to gather information solely by stealing stories from either the AP or the INS (or both)? And did any newspaper steal the information for its own use or for resale from either source?

\section{B. Lifting Stories and Following Tips: The Judicial Response to Custom}

All of these questions raise a common theme: To what extent can one say that there was, by custom and common practice, a system of property rights at work with respect to news stories? If the positivist account of the law is correct, we should expect to see a massive problem of instabihty in the absence of any clear statutory or common law declaration of property rights in this area. Nonetheless, although the record is not as clear on these points as one would hope, it appears on balance that, in general, the situation was as follows: Apart from the cases of bribery and inducement of breach of confidence, which were reasonably limited affairs, the practice of taking stories from bulletin boards or from earlier editions of newspapers was uncommon, even though it was not clearly prohibited by statute or judicial decision. It was only when the British and French authorities cut the INS off 
from the front that it appropriated AP stories. ${ }^{23}$ In dealing with the historical aspects of the case, therefore, the hard question is not why the INS chose to use AP stories. Rather, it is why the taking was so long in coming.

In order to understand that question, one has to return to Hayek's central theme and ask whether it is possible, within the context of property rights im news, to develop some spontaneous order among the players that will coordinate effectively their competitive activities. In this case, the evidence does not all cut in one direction, but it at least suggests that, in some contexts, orders of this sort can emerge without the central control and compulsion of the state. In fact, wholly, or at least largely, without regard to systems of legal enforcement, there was a stable system of customary property rights in news that the competing newspapers respected and clear conventions as to the actions that each party could take with respect to its competitors. $^{24}$ Then the dam broke. An adequate theory of the case, or, inore accurately, the social behavior exhibited in the case, requires that we simultaneously take into account both features-stability and breakdown.

The first point in the analysis is to ask what would have happened if, as a general matter, the news-gathering practices had been otherwise, so that all coiners had a perfect right to publish any news once it was first published in any forn. The judges, generally sympathetic to the position of the AP, well understood the totally destructive nature of the resulting social equilibrium. An example of this judicial attitude is National Telegraph News Co. v. Western Union Telegraph

23 See supra notes $15 \& 21$.

24 Indeed, the scope of the custom need not be limited to news associations that do business in international markets. Throughout the period, it was common to have many local newspapers publish in either inorning or afternoon inarkets. There were ample opportunities to misappropriate stories, yet it appears that there was, and is, within the newspaper profession a powerful norm that tracks that which INS articulated: It is acceptable to follow leads from other papers, but not to lift their stories bodily. See INS, 248 U.S. at 242-43. There appears to be little variation in the norm, or doubt as to its efficacy. Interview with Donna Leff, Professor of Journalism, The Medill School of Journalism at Northwestern University, in Chicago, IIl. (Oct. 1990) (stating categorically that any expert in journalism would testify without contradiction to the strength of that custom today throughout the newspaper business). At the conference at which this Article was originally presented, Professor Edmund Kitch noted that when he was a cub reporter years ago, his initial assignment was to track down leads from stories collected overnight from rival papers. The stories themselves were never used without independent verification. 
Co. ${ }^{25}$ a case Justice Pitney relied on in INS. ${ }^{26}$ National Telegraph had sent its agents over to offices of Western Union's clients to collect the information that Western Uinon liad received and had distributed to its own custoiners. The case, it is important to note, is distinguishable from INS in that the information in National Telegraph was gleaned not froin public bulletins or early editions of eastern newspapers, but froin the displays in the offices of Western Union's patrons, who were bound by contract not to reproduce the information for further distribution. ${ }^{27}$ Nonetlieless, Judge Peter Grosscup's discussion of the effect of allowing the systein of reproduction to continue without legal hindrance reveals the broader issues that lurk behind the legal rule:

It is obvious, also, that if appellants may lawfully appropriate the product thus expensively put upon the appellee's tape, and distribute the same instantaneously to their own patrons, as their own product, thus escaping any expense of collection, but one result could followthe gathering and distributing of news, as a business enterprise, would cease altogether. Appellee could not, in the nature of things, procure copyright under the Act of Congress upon its printed tape; and it could not, agamst such unfair conditions, without some measure of protection, compete with appellants upon prices to be charged their respective patrons. And in the withdrawal of appellee from this business, there would come death to the business of appellants as well; for without the use of appellee's tape, appellants would have nothing to distribute. The parasite that killed, would itself be killed, and the pubhic would be left without any service at any price. ${ }^{28}$

With this statenient, Judge Grosscup counts as one of tlie inadvertent founders of modern game theory. ${ }^{29}$ In effect, lie describes (with

25119 F. 294 (7th Cir. 1902).

26 See INS, 248 U.S. at 237-38. Justice Brandeis, in contrast, gave National Telegraph a back-of-the-hand treatment, citing it along with ten other cases. Brandeis argued that the case stands only for the proposition that information acquired in confidence under contract or trust cannot be passed further on, a point discussed infra Part III.B.2. He acknowledged, however, that although these cases "can, on their facts, be reconciled with this principle, ... much of the language of the courts cannot be." Id. at 252 (Brandeis, J., dissenting).

27 National Telegraph, 119 F. at 295-96.

28 Id. at 296.

29 "Game theory can be described as the study of mathematical models of confict and cooperation between intelhigent rational decision-makers." Roger B. Myerson, Game Theory: The Analysis of Conflict 1 (1990). The typical game involves two or inore players who inust choose anong alternative strategies in order to inaximize their anticipated payoffs. 
an accurate evolutionary analogue) the situation as it would exist if the appropriation of the stories prepared by others were allowed as a matter of course. The parasite can take only what has been produced, and if there is no production, there can be no theft. What holds im biological settings, he observes, holds im commercial ones as well: no service, and, correspondingly, no gains for any relevant parties. In contrast, grantimg the imjunction (and enforcing the contracts) would permit Western Union to gain its return. It also would allow National Telegraph to enter the inarket and obtain a competitive return for itself, thereby benefitimg the public by facilitating a competitive system of quotations. It is clearly a Pareto-superior deal (that is, one that makes one of the parties, National Telegrapl, better off without harming the other, Western Union), at least if the administrative cost of enforcing the contract rights is low, which it assuredly is.

At one level, however, Judge Grosscup is wrong. It need not follow that the equilibrium position without the legal injunction will yield no output. That occurs only if there is no private return that Western Umon could make from its ticker tape services. Even without property rights in its ticker tape messages, Western Umon still might have other advantages from being the first provider of the information that would allow it to continue its operations, albeit on a reduced scale, even after pirating. Western Union also could shift its methods of distribution (by installing tickers only im secured central locations) in an effort to reduce the free riding. Nevertheless, the power of Judge Grosscup's rhetoric does not depend upon the certainty that the corner solution (no output) will be obtained. As a social matter, the injunction is fully warranted if the unrestrained state of affairs leads to a suboptimial collection of the relevant information. The partial destruction of the use of the ticker tapes seems large enough to warrant the protection against the threatened misappropriation.

Empirically, the dommance of the "no misappropriation" solution helps explain why the AP and the INS did not engage early on in systematic appropriation. In fact, there developed an industry custom (as opposed to a conscious agreement), in which all wire services joined, not to use information from rivals' bulletin boards or early editions. On this point, the position taken in the AP's brief is unequivocal: 
Upon this point it is essential to notice the clear and vital distinction between the two kinds of use to which news taken from newspapers may be put.

1. The one use is to send out a story based in whole or in part upon the news obtained from the newspaper without independent investigation or expense. This use may include the sending of a bare statement of the fact of the event, or a inore extended copy of the details of the story of the rival news agency. This is the use practiced by the defendant which the coinplainant seeks to enjoin. This practice has never been recognized as fair or proper among news agencies or newspapers and has never been adopted or authorized by the coinplainant as the District Court found. . . .

2. The other use is to obtain the mere information that a reported event has happened. Upon receipt of this information or rumor the news agency then proceeds, not to verify the news, but to obtain the news by its own independent investigation from the original sources at its own expense and the only story sent out is based solely upon the strength of such investigation. This is the practice which coinplainant admits in the past and which it has been and still is willing that defendant should einploy. ${ }^{30}$

One might question whether this distinction between lifting stories and tracking down tips, drawn as it was from custoinary practice, makes sense in the world of commerce. When the case was decided im the District Court, Judge Augustus Hand-writing as an outsider to the trade-seemed to take the position that it did not, noting

that the original news is ex hypothesi the product of the labor and capital of him who gathers it, and whether it be treated as a inere "tip" for further investigation, or as an authentic and final report, it cannot be used by a rival news agency without depriving the gatherer of the very thing which is of value to him, nainely, the power to control the sale of the news he has gathered until sufficient time has elapsed to enable it to be published by all the newspapers he supphes. Moreover, there is soinething rather grotesque in going through the form of verifying a tip, no matter how authentic it may be. In many cases the verification with modern telephonic communication would be so rapid that the time required for it would in no sense protect the original gatherer of the news. I cannot but feel that this matter of independent investigation is rather a question of business policy, for

30 Brief for Respondent at 65, 67, INS (No. 221). Judge Hand adopted this version of the facts in his opinion. See Associated Press $I, 240$ F. at 991. 
the news service that receives the tip, than of substantive law or fair dealing. ${ }^{31}$

For Hand, therefore, the bottom line is that firms may chose to observe this self-imposed constraint (though, under his analysis, why they should do so unilaterally is a mystery), and that common business practice appears to be completely severed from any legal or social constraints on that practice.

Judge Hand, however, does not consistently maintain the radical severance between social practice and legal rule. Later in his opinion, Hand is forced to return to the AP's custom-based distinction to answer the INS's contention that the "unclean hands" doctrine precluded the AP from obtaining injunctive rehef, given its concession that its agents had engaged in the practice of tracking down tips obtained in other papers. Hand writes:

Nor can it in iny opinion be said that the complainant is barred froin asserting its rights in this case after publication, because it has acted inequitably in making use of "tips" received from the defendant. Both parties have in this respect acted in substantial accordance with common business practice, and under the behef that their conduct was technically lawful. Under such circumstances neither should be debarred from asserting its legal right and obtaining the protection of a court of equity, but a court of equity should only enforce this right if the other party to the suit is awarded similar protection. ${ }^{32}$

In the course of these two paragraphs, Hand exhibits widely divergent attitudes toward the question of industry custom. In the first passage, he belittles the AP's distinction and, in essence, sets up his own sense of the soundness of the practice to undercut the distinction between lifting stories and tracking down tips. His evidence is very much of the armchair variety and assumes that a siniple telephone call will do the business, which in some cases it might, although in many others it will not (after all, phone calls are sometimes not returned). In the second passage, however, he returns to the very distimction that he rejected earher, holding that the AP was entitled to an injunction against the lifting of its stories so long as it agreed to accept a similar limitation upon its own conduct, which it previously had announced it would.

31 Associated Press I, 240 F, at 991.

32 Id. at 995. 
Judge Hand's odd process of reasoning shows how it is possible to make multiple errors in judgment, which have the beneficial effect of canceling themselves out in the end. Against the received wisdom within the industry, he initially sets up his own empirical hunch about the burdens of following up tips. Almost as a inatter of judicial notice, he regards the cost as sinall and hence the distinction as providing less property protection than the AP should have sought. But on such questions of relative costs, the Hayekian imsight that the local information obtained by the players in the industry is far more reliable than the inferences that outsiders draw from general primciples, ${ }^{33}$ surely should be followed. Yet, oddly enough, the local custoin does prevail when the dust settles, for, in structuring his legal rule, Hand refuses to treat all use of a rival's stories as equally iniproper, even thougl he could not have distinguished between them. Rather, he inakes it clear that he would have refused, if asked, to enjoin tracking down tips because both sides engage in it, but he did enjoin lifting information so that neither side would engage in it. ${ }^{34}$ In essence, he sanctions the creation of a property rights regime on the basis of industry custom that rests upon the very distinction that he had disinissed a few pages before as unintelligible.

Both the Second Circuit and the Supreine Court took a inore favorable attitude toward the distinction. The Second Circuit, speaking through Judge Charles Hough, held exphicitly that " $[t]$ here is no difficulty in discriminating between the utilization of 'tips' and the bodily appropriation of another's labor in accumulating and stating

33 John Gray describes the Hayekian approach as follows:

For Hayek is at great pains to point out that the dispersed knowledge which brings about a tendency to equilibrium in economic life and so facilitates an integration of different plans of life, is precisely not theoretical or technical knowledge, but practical knowledge of concrete situations-" "knowledge of people, of local conditions, and of special circumstances." As Hayek puts it: "The skipper wlio earns his hiving from using otlerwise empty or half-filled journeys of tramp-steamers, or the estate agent whose whole knowledge is almost exclusively one of temporary opportunities, or the arbitrageur who gains from local differences of coinmodity prices-are all performing eminently useful functions based on special knowledge of circumstances of the fleeting moment not known to others."

Gray, supra note 8, at 36 (quoting Friedrich A. Hayek, The Use of Knowledge in Society, in Individualisin and Economic Order 77, 80 (1948)). The constant references to "local," "teinporary," and "fleeting" capture the news business to a "T."

34 Associated Press I, 240 F. at 995-96. 
information,"35 and in the Supreine Court, Justice Pitney, with a bit more caution, wrote that "[w]e are inclined to think a distinction may be drawn between the utilization of tips and the bodily appropriation of news matter, either in its original form or after rewritimg and without independent investigation and verification." $" 36$ In both instances, I think that the appellate courts' instincts were better than Judge Hand's, but the methodology still was flawed because both Hough and Pitney relied too heavily on their independent cogintive judgments about the inherent plausibility of the distinction and less upon the practices within the industry that led to its creation.

\section{A Rational-Choice Explanation for a Common Practice and Its Breakdown}

Although I beheve custoin and common practice offer rehable guides to choosing the right set of property rights and hability rules, we do not have to accept the news-gathermg custom on blind faith. Rather, by looking inore closely at its two constituent practices, it is possible, I think, to give a formal, rational explanation of how they are able to create a sensible customary structure, one that should prove stable in most (but perhaps not all) circumstances. ${ }^{37}$

By refraining from wholesale misappropriation of their rivals' stories, the parties can avoid the degenerative social equilibrium that Judge Grosscup described in National Telegraph. ${ }^{38}$ Each party knows that the danger of retaliation is so great that once it decides to adopt a free-rider position, it will, over time, lose its own investment in the news-gatherimg business. As repeat players, the newspapers that rely upon these agencies or constitute their membership or chents also must fear the destruction of their sources of information, which constitutes a powerful incentive to respect the customary rules in their ordinary business. The newspaper that tried to rely solely on renegade sources for its news stories would have, at best, an intermittent and unrehable source of information and would be outside the pale of respectable society in its news-gathering practices. A strong dose of

\footnotetext{
35 Associated Press $I I, 245$ F, at 247.

36 INS, 248 U.S. at 243-44.

37 For further discussion of the preconditions for the emergence of custom, with special reference to the law of tort, see Epstein, supra note 3, at 12-17.

38 For a quotation of the relevant discussion, see supra text accompanying note 28 .
} 
community self-survival and individual self-interest thus should help to preserve the basic overall equilibriun.

We can account similarly for the second part of the practice-the use of tips from other news agencies. This practice does not pose a threat to the overall stability of the enterprise comparable to lifting stories. So long as there is independent investigation of the tip, and so long as the information printed in the story is obtained through that mvestigation, a firm will be able to take advantage of the tips only if it already has an extensive news collection agency in place. Within this framework, using tips across the board allows all the papers to lower their cost of collecting information, without destroying the initial incentive to produce information in the first place. Thus, if the independent investigation takes any time at all, then the original producer of the information still preserves an important part of its temporal advantage over its rival.

Because the practice of following these tips is acknowledged to be universal, it does not confer any obvious distributional benefit on one firm over another. Quite the opposite, following tips enables all of the players to lower their costs, which benefits the overall marketplace, including the consuiners who will enjoy superior access to news. In effect, by usimg tips, each side gets inıphcit im-kind compensation from the exception to the basic norm agamst the inisappropriation of others' stories.

The interaction of these two customary practices, therefore, seeins to have powerful efficiency benefits for the operation of the industry as a whole. The argument, of course, depends upon the level of cost differences between lifting stories bodily and tracking down tips. It also depends upon a perception that self-interest is so strong, and monitoring so difficult, that no norm that forbade the use of tips could ever survive. There may well be more at stake than this outsider's view of the industry can detect, but, for present purposes, the persistence of the distinction between following tips and liftimg stories made and adhered to within the trade, both at the time of INS and now, provides the best evidence that this distinction is substantial enough to count.

\section{The Analogy of Self-Enforcing Contracts}

In dealing with this two-part custom, there is an instructive analogy to the logic of self-enforcing contracts in the context of ordinary 
exchange transactions. In a world in which there are only one-shot exchanges, we should not expect to see self-enforcing contracts except in those cases in which the exchange is simultaneous, itself a highly restrictive condition to satisfy because soineone inust hand over something first. ${ }^{39}$ The party that performs first has, in essence, surrendered a thing in exchange for a proumse that is worthless if not kept. It is a promise that a self-interested promisor will not keep voluntarily, for he is better off keeping both the money and the thing. The entire logic for accepting the Hobbesian sovereign rests on the party's ability to make sure that the second half of the voluntary exchange will take place once the first is completed, for if it does not, then the first part of the exchange will not take place at all..$^{40}$

The introduction of repeat transactions, however, changes the strategies for the individual players. The probability of entering into gainful exchanges in the future normally has a positive value to both players. As rational actors, these players have to take into aceount these inchoate relational gains along with the gains or losses that they may incur on the immediate transaction. If $X$ parts with a thing worth $\$ 100$ on the strength of $Y$ 's prolmise to pay $X \$ 100, Y$ will not keep both the thing and the money if the value of future dealings with $X$ is worth over $\$ 100$ to $Y$. In this situation, if $Y$ decides to keep both the thing and the money, $Y$ 's short-term act of self-interest leaves $X$ with no other choice but to refuse to go first in other exchanges with $Y$, so $X$, having lost the thing, has nothing to gain from keeping alive a relationship that promises her only a string of future losses. $Y$ is left worse off as well because the $\$ 100$ gained is smaller than the future profits from continuing his trading relationship with $X$. There is,

39 Indeed, the whole practice of escrows and brokers arises to introduce long-term repeat third-party players when exchanges cannot be simultaneous.

40 See Douglas G. Baird, Self-Interest and Cooperation in Long-Term Contracts, $19 \mathrm{~J}$. Legal Stud. 583 (1990). Even in the absence of the Hobbesian sovereign, as Anthony Kronman demonstrated, the parties can adopt certain strategies to bind theinselves to forward contracts without legal enforcement, such as the giving of hostages, or the tailoring of specific goods to the needs of the other party, so that its value in alternative use is destroyed although its value in exchange is preserved. See Anthony T. Kronman, Contract Law and the State of Nature, 1 J.L., Econ. \& Organizations 5 (1985). Note that there is no reason why the legal and nonlegal reinedies should be thought of as mutually exclusive. If the nonlegal devices are able to reduce the likelikood or severity of breach, then the legal sanctions, even if costly and imperfect in themselves, may be strong enough to allow the overall system of exchange to go forward. 
then, a stable relationship between $X$ and $Y$, even if there is no legal enforcement of any discrete exchange transaction.

The point can be generalized. The secret for preserving self-enforcing exchanges is to make sure that the property or money that is transferred from one side to the other is always worth less to the reeipient than his or her contimued maintenance of the exchange relationship. From this basic poimt, three conclusions follow. First, selfenforcing contracts have limited efficiency in that the size of the imdividual transaction cannot become too large im relation to the parties' valuation of future trades between them. Second, self-enforcing contractual relationships are difficult to maintain for any fixed, limited period, for, as the end of the relationship comes closer, the anticipated gains to each side from future trades diminish, which imcreases the likelihood that one side will welch if given the opportunity. Third, any system of self-enforcing exchanges over time runs the risk that sudden shifts im external circumstances, such as the outbreak of war or changes in weather conditions or technology, will change radically the value of the goods or money that are handed over, relative to the future value of the exchange.

This model of self-enforcing contracts need not be limited to a set of serial exchanges between two parties. It could well explain the imperfect durability of customary practices against unilateral defections in other contexts-imcluding the news-gathering busmess. Even though there are no direct exchanges between the various agencies, each of them faces a breach-or-perforn choice that is sunilar to $X$ 's and $Y$ 's in the above example. To perform is not to lift a rival's stories; to breach is to do so. In each case, the risk of retaliation is so great that no player in the busmess will want to take the first step and defect. ${ }^{41}$ Therefore, it will not be in the present long-terin imterest to pirate stories because pirating, if too successful, will kill (or radically transforin) the host or lead to retaliation.

41 As an aside, it is clear that individual enployees have somewhat greater incentives to cheat on these relationships because they get all the short-term gains of not complying with the industry norm, but only a tiny fraction of the losses. It is, therefore, no accident that the AP in its brief went to great pains to note that any violations of the industry norms were frowned upon by its senior persounel who took strong measures to counteract thein. See Brief for Respondent at 65, INS (No. 221). 


\section{E. War and Disequilibrium}

The secret of the self-enforcing contract, then, is to ensure that the short-term gains from defection never exceed the long-term benefits from preserving general stability. But these short-term gains from defection may be increased dramatically by events beyond the control of the parties, which would undermine the apparent permanence of the overall relationship. Just that happened in INS. Once barred from the European theater, the INS's private calculations changed radically. Pirating stories becaine necessary to keep INS papers in coinpetition with their AP rivals-without access to the front, no phone call or investigation could follow up on a teinpting lead. Not having information from the front imposed an enormous short-term cost on the INS, one sufficient to justify some long-term risk. Although there may have been sporadic pirating from the time the INS was formed in $1909,{ }^{42}$ the practicc of lifting stories probably started in earnest, as INS policy, only after the British and French troops barred its reporters from the European theater.

Interestingly, the INS apparently adopted a strategy designed to allow it to offset its enormous short-term disadvantage without upsetting the entire fabric of the customary system of property rights that had developed. It seems the INS limited its acts of misappropriation to tlose cases in which it lacked direct access to the events underlying the news. In so doing, it, im essence, adopted as its own working norm a "necessity" or "just cause" exception to the basic norm, while signaling to the AP its willingness to follow the conventional rules on news-gathering on all other fronts.

The AP, for its part, clrose its strategy with similar restraint. It did not engage in self-help by stealing stories from the INS in the markets where the INS still operated, even if it could have used the stories itself. Nor is there any reason to think that it chose not to use INS stories solely because it doubted their accuracy: the whole issue of lifting stories arose precisely because the practice does pay in the short run. Instead, the AP's studied response is best understood as an effort to avoid increasing the risks of spreading the destructive equilibrium across the board. The AP could not retaliate in a limited

42 The AP alleged that the INS had lifted stories "[e]ver since the organization of the defendant," Transcript of Record at 12-13, INS (No. 221), but the actual record shows no systematic signs of piracy outside of the war context. 
fashion by stealing INS stories from the European theater in good titfor-tat style; therefore, it chose not to retaliate at all but imstead sought mjunctive rehef through the courts.

The two pieces of the puzzle thus fitted together well. Both sides sought to partition the difficulties of collecting news from the European theater from the more general question of what rules govern the acquisition of property rights in news. In this backhanded fashion, both implicitly acknowledged the system of informal property rights that had evolved in the news industry without any apparent legal intervention. Similarly, all other players in the market, having access to the European theater, continued business as usual. There was thus a confined local exception to the general rule against lifting stories.

Taking into account the drainatic shifts in access to news on the European front explains both how the basic legal rule survived as long as it did, and why it failed when it did. This general account also gives some sense as to the soundness of the customary rule. When push came to shove, the legal system adopted the customary rule. In the next Part, I turn from the custom and practice over information in news to the formal legal analysis of the topic.

\section{INS AS LAW \\ A. The First Possession Rule}

In one sense, the easiest way to defend the result im INS is to recognize the force of custom in the creation of the property rights. Nonetheless, as the case wound its way through the courts, neither of the parties exphicitly argued that property rights should follow the custom of the industry. Instead, the parties approached the property right issue as Justice Story did in The Reeside $:^{43}$ matters of first legal principle had to be brought to bear on the case. Because of this focus on legal principles rather than on custom, the disruption of the INS's service was not mentioned at all in Justice Pitney's majority opmion and was mentioned only in passing in Justice Brandeis' dissent to criticize the rigidity of the Court's ruling. ${ }^{44}$

In this Part, I will unpack the legal arguments used to defend property rights in news and explain their strengths and weaknesses im deal-

4320 F. Cas. 458 (C.C.D. Mass. 1837) (No. 11,657). For a discussion of Story's positivist approach, see supra text accompanying notes 5-6.

44 See supra note 21 and accompanying text. 
ing with the situation in which the AP and the INS found themselves. The discussion proceeds at a solnewhat high level of abstraction, for the topic is the origin of, and justification for, property rights. Even with land, the origin of these rights is a "1nystery" that no one has fully been able to unpack, at least to the satisfaction of others. ${ }^{45} \mathrm{~A}$ fortiori, then, intellectual property, although recognized early on as a species of property, has special difficulties of its own. ${ }^{46}$

The best way to proceed in the analysis is to begin with the standard accounts of property rights at common law and to see how they square with the creation of the property interests in news in INS. My primary purpose here is not to criticize or to justify the common law responses. Rather, iny main goal is to use the theory of the common law to gain insight into the peculiar difficulties presented in INS and subsequent cases.

As is familiar, the single rule for initial acquisition of ownership of land or chattels at common law is the rule of first possession. That rule holds that anything in the initial position (that is, something that no one possesses or owns) is a res nullius-a thing owned by no one. ${ }^{47}$ The act of possession and occupation takes things from the initial position and confers upon the first taker the full rights of ownershipthe rights of possession, use, and disposition. ${ }^{48}$ In general, these own-

45 See Douglas G. Baird, Common Law Intellectual Property and the Legacy of International News Service v. Associated Press, 50 U. Chi. L. Rev. 411, 413 (1983).

46 As Judge Grosscup reasoned in National Tel. News Co. v. Western Union Tel. Co., 119 F. 294 (7th Cir. 1902):

Property, even as distinguished from property in intellectual production, is not, in its modern sense, confined to that which may be touched by the hand, or seen by the eye. What is called tangible property has come to be, im most great enterprises, but the embodiment, physically, of an underlying life-a life that, in its contribution to success, is immeasurably more effective than the mere physical einbodiment. Such, for example, are properties built on franchises, on grants of government, on good will, or on trade names, and the like. It is needless to say, that to every ingredient of property thus made up-the intangible as well as the tangible, that which is discernible to mind only, as well as that susceptible to physical touch-equity extends appropriate proteetion.

Id. at 299.

47 See W.W. Buckland, A Text-Book of Roman Law From Augustus to Justinian 183-84 (3d ed. 1963).

48 See James Tully, A Discourse on Property: John Locke and His Adversaries 126 (1980); see also United States v. General Motors Corp., 323 U.S. 373, $377-78$ (1945) (noting that the concept of property denotes a person's relation to the possession, use, and disposal of a physical thing). 
ership rights are infinite in their duration-in sharp contrast to the very short periods of temporal ownership of news claimed in INS. ${ }^{49}$

There is, of course, an enormous dispute over the possible justifications for the common law rule of first possession. One highly influential justification is John Locke's so-called "labor theory" of property. ${ }^{50}$ In essence, the theory provides that those persons who have "mixed" their labor with what nature has provided have earned the right to treat the things so acquired as their own. ${ }^{51}$ The labor theory of ownership has been defended on the grounds that it protects persons in their labor and gives them proper incentives to improve and to develop the property in question. ${ }^{52}$ There are many internal difficulties with this theory, the chief perhaps being that it does not explain why individuals own their labor in the first instance or why they are entitled to receive the full value of the improved property instead of the incremental value thereof..$^{53}$

In place of the labor theory of property, it is possible to develop an alternative justification for the first possession rule, one which deals more with problems of social coordination and less with a natural theory of desert. By this alternative conception, the distribution of property rights in the original position is a functional question, forward-looking in orientation, in which the central task is to develop that initial distribution of rights that leads to the shortest path for the productive use of natural resources-that is, to soine form of allocative efficiency. ${ }^{54}$ Under this theory, individuals have sole ownership of their labor because that assignment of rights facilitates inarket transactions in labor far better than any alternative. ${ }^{55}$

49 See INS, 248 U.S. at 234-36.

so John Locke, Two Treatises of Government 133-46 (Thomas I. Cook ed., 1947) (6th ed. 1764).

51 Id. at 134.

\$2 For various views on the labor theory of value, see Lawrence C. Beeker, Property Rights: Philosophic Foundations 32-57 (1977); C.B. Macpherson, The Political Theory of Progressive Individualism 194-221 (1962); Stephen R. Munzer, A Theory of Property 254-92 (1990).

53 See generally Richard A. Epstein, Possession as the Root of Title, 13 Ga. L. Rev. 1221, 1225-30 (1979) (discussing shortcomings of the labor theory of property rights).

54 See Richard A. Epstein, Luck, 6 Soc. Phil. \& Pol'y 17, 26-28 (1988) [hereinafter Epstein, Luck]; Richard A. Epstein, The Utihitarian Foundations of Natural Law, 12 Harv. J.L. \& Pub. Pol'y 713, 730-37 (1989) [hereinafter Epstein, Utilitarian Foundations].

55 See Epstein, Luck, supra note 54, at 26-28; Epstein, Utilitarian Foundations, supra note 54 , at 730-31. 
Whatever the precise theoretical justification of the common law, the same results obtain once the initial premises of individual selfownership and private property acquired through possession (or labor) are accepted. ${ }^{56}$ In either case, individuals own both their labor and the property acquired with it. Usually, protecting the property itself, whether by actions of trespass or conversion, is sufficient to protect the labor invested in its improvement, without any independent action. The common law, therefore, essentially adopts the libertarian view, which protects property rights against the aggression of strangers and allows the recoinbination of property rights through voluntary exchanges that may be repeated as often as the owners of resources like. ${ }^{57}$

\section{B. Property Rights in News}

The first question that faced the justices in INS was whether this classical common law model of property or the common law doctrines of contract and tort could resolve the case. In order to understand how these common law theories influenced the opmions in INS, it is important to note those portions of the case that were uncontroversial and, therefore, not before the Supreme Court. These fall into two classes: misrepresentation, or "passing off," as a species of unfair competition, and induceinent of breach of contract.

\section{Misrepresentation and Passing Off}

The first possible approach to INS is to ask whether the AP could have obtained its injunction by relying on the nornal tort theories of misrepresentation. The answer is, probably not. The usual case of misrepresentation involves a false statement by the defendant to the plaintiff or to a third party that induces some action to the plaintiff's detriment. In INS, the INS made no misrepresentations to the AP, so everything turns on the misrepresentations, if any, that the INS made to third parties. That issue is captured at common law, for example, in the tort of passing off, the gist of which is that the defendant claims that the goods he sells are the (superior) goods of the plaintiff. This

56 See Baird, supra note 45 , at 423.

57 There is a close connection between this critical component of a common law theory and the "historical" theories of justice (that is in acquisition, protection, and transfer) that Robert Nozick subsequently developed with great elegance and ingenuity. See Robert Nozick, Anarchy, State, and Utopia 149-82 (1974). 
case presents a variation on a familiar theme in that the INS lifted stories from the AP wire without disclosing the source of its information. Many INS subscribers may have been unwilling to take or to use the bulletms had they known how the INS had acquired them.

There are two objections to this theory on the facts of INS. The first, pressed by Justice Brandeis im his dissent, is that silence as to source should not be treated as though it were an affirmative representation, absent any clear duty to disclose. ${ }^{58}$ The second, pressed by Justice Holmes, is that even if silence counted as improper concealment given the course of dealing, the AP was not entitled to the sweeping imjunctive relief the courts awarded, which enjomed the INS from using news bulletins and stories lifted from AP sources. ${ }^{59}$ As Holmes put it im his concurrence: "[A]s, in my view, the ouly ground of complaint that can be recognized without legislation is the imphed imisstatement, it can be corrected by stating the truth; and a suitable acknowledgment of the source is all that the plaintiff can require." 60 Consequently, the imsrepresentation theories, standing alone, could not get the AP the rehef it sought.

\section{Inducement of Breach of Contract}

The shortcomings with the passing-off theory bring us to inducement of breach of contract, the second cominon law theory that influenced the result in INS. As Judge Hand summarized the first two allegations, they faulted the INS for "[a]rranging with employés of members of the Associated Press to furnish its news to the defendant for a consideration [read: bribe] before publication" and "inducing [AP] members to violate [AP's] by-laws and permit defendant to obtain news of the Associated Press before publication."61 Hand enjoined these practices largely because they fell within the common law rule that imducement of breach of contract is a tort. ${ }^{62}$ The apphcation of the rule makes good sense im this case because it makes it clear that no one can knowimgly take information from which he has

58 See INS, 248 U.S. at 260 (Brandeis, J., dissenting). In so arguing, Brandeis takes a strongly libertarian view of the common law of unfair competition.

59 Id. at 247-48 (Holmes, J., concurring).

60 Id. at 248 (Holmes, J., concurring).

61 Associated Press I, 240 F. at 985.

62 Id. at $985-88$. 
been lawfully excluded. ${ }^{63}$ That we deal here with the passage of information, instead of the services of an opera star, ${ }^{64}$ or workers involved in a labor dispute, ${ }^{65}$ is quite immaterial. What matters is that the tort apphes to cases where the defendant acts with knowledge of the plaintiff's relationship to the third party, in order to induce the third party to sell to him what has been promised exclusively to another.

The critical question is how far the remedy for the tort goes. At one level, that is a function of the contracts in question that are to be breached. Historically, the inost relevant Supreme Court authority on this point was Board of Trade v. Christie Grain \& Stock Co. ${ }^{66}$ There the defendants were traders in grain who sought to use the quotations generated by the Chicago Board of Trade, even though they were not members of the organization. In order for them to do so, they had received the information froin subscribers to the Board of Trade's service, who had received the information from the Board of Trade under an agreement that they would use the information in confidence (that is, would not pass it on to anyone outside the circle of subscribers). The Supreme Court, speaking through Justice Holmes, enjoined the defendants' use of the information on the ground that the Board of Trade

does not lose its rights by communicating the result [the grain quotations] to persons, even if many, in confidential relations to itself, under a contract not to inake it public, and strangers to the trust will be restrained froin getting at the knowledge by inducing a breach of trust and using knowledge obtained by such a breach..$^{67}$

In essence, the confidential relation cases rely on the common law tort of inducement of breach of contract, which works because the inforination was disseminated only to individuals who took the information impressed with the limitation on its use.

63 See generally Richard A. Epstein, Inducement of Breach of Contract as a Problein of Ostensible Ownership, 16 J. Legal Stud. 1 (1987) (coinparing induceinent of breach of contract to cases where a purchaser is willing to buy froin a thief or faithless bailee property known to belong to a third party).

64 See Lumley v. Gye, 2 El. \& Bl. 216, 118 Eng. Rep. 749 (1853).

65 See Hitchman Coal \& Coke Co. v. Mitchell, 245 U.S. 229 (1917). Ironically, Justice Pitney wrote the opinion in Hitchman Coal over a Brandeis dissent. My support of Pitney's position in Hitchman Coal is set out at length in Richard A. Epstein, A Common Law for Labor Relations: A Critique of the New Deal Labor Legislation, 92 Yale L.J. 1357 (1983). 66198 U.S. 236 (1905).

67 Id. at $250-51$. 
The question in INS was whether it is possible in principle to go beyond the confidential relation cases. In dealing with the issue, Judge Hand wrote: "In the stock and grain quotation decisions the right has been likened to a trade secret. But in all these cases there is hittle basis for anything like secrecy, and there is often no real contract not to disclose what is published." ${ }^{\prime 68}$ This view of the situation seeins at odds witli Holmes' inore limited statenent in the Christie decision, and it makes INS easy for the AP as a matter of precedent because it assumes that the protection afforded in the prior quotation cases had to rest on a limited property right in infornnation - that is, to the quotations-that existed apart from contract.

On this point at least, lowever, Justice Brandeis is surely correct im his INS dissent when he notes that a network of contracts is as good as a single bilateral connection so long as there are no gaps in the chain. ${ }^{69}$ The relief provided in Christie does look like tlie contractual protection afforded trade secrets and not the protection norinally created by systems of property rights, such as the patent law. At first blush, the radical and principled difference between Christie and INS is that publication to the world is not the saine as publication to a limited audience, so that the tort theory of mducement of breacli of contract is mapplicable in INS. ${ }^{70}$ As both traditional tort theories fail, it looks as though the AP should be without a remedy.

\section{Property, or Quasi-Property, in News}

Justice Pitney does not rely on either the misrepresentation or inducement of breach of contract cases to make the whole of his argument in INS. Instead, he rests upon the idea of property rights in news. To set the stage for his argument, Pitney outlimes the relevant questions as follows:

1. Whether there is any property in news; 2 . Whether, if there be property in news collected for the purpose of being published, it survives the instant of its publication in the first newspaper to which it is communicated by the news-gatherer; and 3 . Whether defendant's admitted course of conduct in appropriating for commercial use mat-

68 Associated Press I, 240 F. at 992 (citation omitted).

69 INS, 248 U.S. at 251-53 (Brandeis, J., dissenting).

70 Judge Hough drew this distinction in his opimion for the Second Circuit in Associated Press II, 245 F. at 250, arguing that there was no publication until all pnblications had been inade, a point that seeins wrong as a matter of description. 
ter taken from bulletins or early editions of Associated Press publications constitutes unfair competition in trade. ${ }^{71}$

Pitney answers all three questions in the affirmative, as he must in order to hold for the plaintiff, but there are some evident difficulties im his analysis. First, consider the mode of acquisition. In the normal case, property in external things is acquired by taking first possession of them. But what is it that is possessed here? Surely it cannot be the right to be the sole person to speak about the event, which is news itself. Those events are open for all to see and to analyze as they see fit, and the fact that one company decides to send its team of reporters to investigate a story does not preclude others from following suit. Indeed, the thought that only persons who deal with the AP can speak of Pearl Harbor after it breaks the story, for example, is too grotesque to admit any serious consideration. The social loss, the giant-size externahity of massive ignorance, that would result froin the creation of so extensive a property right is too large to deny.

On the other side, no holdout problems arise by allowing multiple parties to gain access to the same public events. Quite the opposite, having many separate parties cover the saine event only serves to increase the options available to consumers and to mitigate the harmful effects of monopoly. In this context, the twin concerns with externalities and holdouts (which drive the rules on property generally) are not in opposition to each other, but cut in the same direction, so that the resulting system of property rights clearly favors socialization. Pitney himself adheres to this line: "the news element-the information respecting current events contamed in the hterary production-is not the creation of the writer, but is a report of matters that ordmarily are publici juris; it is the history of the day."72 In other words, there are no property rights in historical events.

The fear of giving the first newspaper to report on an event the exclusive right of coverage, however, does not undermine the case for recognizing property rights in the stories about the historical events. But even if so confined, property rights in tangibles acquired at cominon law under the first possession rule usually possess two key characteristics. First, they are good against the rest of the world, and second, they are of infinite duration. Neither of those conditions is

71 INS, 248 U.S. at 232.

72 Id. at 234. 
satisfied with a property right in news. The tipoff that something is stightly amiss is verbal: Pitney describes the defendant's interest in its news as "quasi property," which is good only for a short period of time (less than a day) and then only against the direct competitor of the plaintiff:

Regarding the news, therefore, as but the material out of which both parties are seeking to make profits at the same time and in the saine field, we hardly can fail to recognize that for this purpose, and as between them, it inust be regarded as quasi property, irrespective of the rights of either as against the public. ${ }^{73}$

There are good reasons to have strong property rights in tangibles and weaker ones in news stories, for, as Professor Douglas Baird has noted, there are important differences and similarities between land and information. ${ }^{74}$ With land, the first possession rule assigns ownership rights to the first taker. In so doing, the rule imposes two kinds of costs: first, it induces persons to take possession of the land prematurely, before they need it for use and production, and second, it imposes losses on those who do not win in the early chase. The justifications for the first possession rule are that it avoids the endless holdout problems over the disposition of resources and sets up decentralized systems of property rights that facilitate the organization of a inarket. ${ }^{75}$ Once soineone obtains these property rights, however, it makes sense that they be of infinite duration (that is, held in fee simple). Any shorter interest would raise the question of who will possess at the expiration of the term and inake it more costly for the original owner to make valuable improvernents to the property, if some of the benefits will inure to some new taker of the land in question. Because ordinarily only one person can use a piece of land efficiently at any given time, giving the ownership im fee does not cut out subsequent deployment. Exclusivity in perpetuity, therefore, coines at a very low price for land.

Information, as an intangible, raises very different problems. Here there is a need to spur the creation of the property in question, which is perhaps analogous to the need for spurring the discovery of valua-

73 Id. at 236.

74 See Baird, supra note 45 , at $413-14$.

75 See Richard A. Epstein, Past and Future: The Teinporal Dimension in the Law of Property, 64 Wash. U. L.Q. 667, 669-70 (1986); see also Epstein, Luck, supra note 54, at 26-28 (saine); Epstein, Utilitarian Foundations, supra note 54, at 730-37 (same). 
ble land, such as land containing valuable mineral rights. But once the property is effectively developed, the information may well have greater value if it is used by many people simultaneously than if it is used and kept by one person alone (a new mathematical theorem may be a good illustration of this phenomenon). Therefore, granting perpetual property rights in information creates, at the margin, small additional incentives to gather the information, but it reduces, no doubt to a far greater extent, the beneficial use of the information once it is made available.

News differs from other forms of information in which property rights are created. With news, the economic return obtained by the newspaper is concentrated very highly in the first period after its use, usually within twenty-four hours or less. A system that grants property rights for that limited time is apt to create powerful imcentives for the collection of news and to make the information widely available thereafter without costly transactions between the countless users of the information and the many supphiers of that information, each of whom has, or may claim to have, provided some fraction of it. It is a transactional mightmare to assume that all researchers and analysts who read both INS and AP papers will be barraged with claims for restitution for value provided. The system of property works quite well if the news services can keep their exclusive rights relative to each other for a short period of time, which is what the Pitney rule did.

The basic point can be made forcefully in cost/benefit terms. The tradeoff between acquisition ex ante and utilization ex post is quite different for news than it is for chattels. In the latter case, there is no social loss from having the exclusive property rights of the first possessor retained in perpetuity. With agricultural land, only one person can efficiently reap the crops after they have been sown. A free-for-all on harvest would be destructive of the entire system of agriculture. It follows that the tradeoff between the creation of valuable resources and their maximal utilization simply does not arise with land. The system of perpetual exclusive ownership of land maximizes the value of that sort of resource. That system, however, is flawed for intangibles such as news, where multiple use, given its mitial creation, mcreases overall value. Given the differences in the utilization patterns of tangibles and intangibles, Pitney's cautious characterization of the right in news represents an intelligent response to the tradeoffs 
in question. The cost/benefit analysis and the custom thus track each other well.

In this regard, moreover, there is a strong difference between the protection that is provided to news as quasi-property and that which is provided to copyrights, another form of intangible with quite different characteristics. At one level, ordinary copyright protection is insufficient in the short run because a rewrite of the news story does not offend copyright, although it results $m$ the misappropriation of the AP's effort to collect the information for the story. Yet, in another sense, copyright protection is overbroad, for the optimal length of copyright protection, always ineasured in years, is wildly excessive for news. The individual story, as opposed to the information that it contains, is soinething that can vest for long periods of time in one person without impeding the ability of others to do their work. Because the payoff froin a book or a story is not heavily concentrated in the first twenty-four hours of its publication, longer periods of protection are normally required to generate the promised return that will induce the labor in the first place. ${ }^{76}$ Pitney is quite right to assume that one can deal with the special rules governing news without having to call into question the separate protection, afforded for very different periods of time, for copyright. ${ }^{77}$ The great irony is that Brandeis, whose seminal article on privacy celebrated the capacity of the common law to grow in response to new issues, ${ }^{78}$ was willing to dump the issue of the creation of property rights in news back into the lap of Congress, which had failed to pass such a statute a few years before INS was decided. ${ }^{79}$

In making these elaborate calculations, it is clear that Pitney does not expressly rely upon the customary practices within the industry to

\footnotetext{
76 The present law sets the period of copyright protection at life plus 50 years. 17 U.S.C. $\S 302$ (e) (1988). It does not set it for a period of $X$ years after publication, perhaps on the view that it is easier to determine the date of death than it is the date of publication. The result, of course, is that works written by young authors with long life expectancies receive greater protection, in terms of years, than is received by old authors who, by defintion, have inuch shorter life expectancies. For a discussion of the optimal length of copyright protection, see William M. Landes \& Richard A. Posner, An Economic Analysis of Copyright Law, $18 \mathrm{~J}$. Legal Stud. 325, 361-63 (1989).

77 See INS, 248 U.S. at 234-36.

${ }^{78}$ Samuel D. Warren \& Louis D. Brandeis, The Right to Privacy, 4 Harv. L. Rev. 193 (1890).

79 INS, 248 U.S. at 264-65 (Brandeis, J., dissenting).
} 
account for the result in the case. Yet he inanages to produce, by diverging at the two critical junctures froin the standard conception of common law rights, the very same distribution of outconnes that would have been achieved if he had simply decided that custom within the industry set up the property rights as between industry competitors. The industry norm inade no effort to charge end users anything more than the cost of the newspaper or to stop the use of tips by coinpetitors, but did prohibit the lifting of stories from bulletim boards and early editions of papers. ${ }^{80}$ That, in essence, is Pitney's position.

The weakness of Brandeis' and Holmes' positions was that they stayed too closely wedded to common law conceptions of force and fraud, too close to the standard forms of property rights in chattels and writings. At no point did they see those rules as means to achieve some overall conception of social welfare. To be sure, in the normal case the protection of labor is well-achieved by rules that protect the fruits of labor-rules that allow one to reap what one has sown ${ }^{81}$ and preserve the sanctity of contract. But here the labor, skill, and money invested by the defendant created information that was not embodied in any tangible thing, so some deviation from the common law conceptions had to be made in order to achieve higher levels of social output, shared by all, from a given set of scarce resources. The risk of seeking out the immutable rules of positive law is that, had the composition of the Supreine Court been different, the three dissenting voices in $I N S^{82}$ would have estabhished the legal norms for an industry whose internal operation they scarcely understood.

\section{The Necessity Exception}

Although Pitney reached the correct result in INS, there are limits to his success as well. At no point in his opinion did he seek to take into account the effects of having the INS cut off from news froin the

80 See supra note 24.

81 Justice Pitney uses the reap-what-you-sow metaphor to support the result in INS. See infra text accompanying note 92 . The proposition makes great sense in agriculture, where it is more than a metaphor, for it captures the idea that no one will plant if others can harvest one's crops, thus showing the imstrumental justification for exclusive property rights in land.

82 Holmes was joimed in his partial concurrence by Justice Joseph McKenna. Because he agreed with Brandeis on the main issue, the vote in the case was 5-3. Justice John Clarke did not participate. 
European theater. That change in events, as noted above, radically altered the game for all parties, and the question is whether those changes should have been reflected in the law. Here there is, moreover, ample reason to beheve that some adjustment was appropriate.

Even though the ordinary common law rules of private property allow for the absolute exclusion of others from land possessed by the owner, it long has been understood that these rules may be suspended in cases of necessity. A person stranded at sea, for example, may use force against an owner to reach a position of safety, even if he has to compensate the owner for any damage to the property. ${ }^{83}$ The basic intuition behind these necessity cases is a sound one. In necessity cases, a system of absolute and exclusive property rights that normally promotes mdustry and trade imposes incredible bargaining and holdout problems in situations where the (next best) value in use of the land to an owner is a tiny fraction of the value of the use of that land to a person in peril of his life. ${ }^{84}$

The exact contours of the necessity doctrine are beyond the scope of this Article, but its implications are relevant to one central question: What happens when customary practices, based on a norin of equal and open aceess, are transforined in an environment where a foreign government excludes some persons? Does necessity allow the inforination to be taken from the other, but (and here is the rub) only on payment of just coinpensation, as when land is taken or used in circnmstances of necessity? Should, in otlier words, the INS unilaterally liave been able to avail itself of AP stories for soine fraction of AP's cost of producing tliem-the relevant just compensation-until it was able to reestablish itself in the market?

This alternative is not without its costs, especially if it invites direct bargaining between the two orgamzations. If the AP and the INS wanted to combine their operations generally, there would be soine question as to whether the combination (viewed eitlier at the member or the entity level) would be an illegal restraint on trade of the sort prohibited by the Sherinan Act. ${ }^{85}$ Yet another problem cannot be ignored: If the two sides did bargam with each other, and the British

83 See, e.g., Vincent v. Lake Erie Transp. Co., 124 N.W. 221 (Minn. 1910); Ploof v. Putnam, 71 A. 188 (Vt. 1908). For a short account of the role of necessity more generally, see Richard A. Epstein, Property and Necessity, 13 Harv. J.L. \& Pub. Pol'y 2 (1990).

84 See cases cited supra note 83 .

8515 U.S.C. $\S \S 1-7$ (1988). 
and French governments got wind of the situation, then they might have banned the AP as well. But, because they did not tie the legal rules back to the customary practices and institutional framework from which they derived, the hitigants overlooked the very possibility that (for a mouthful) ostensibly absolute quasi-property rights should be defeasible in cases of necessity. And it seeins a pity, for, on the merits, recognizing a necessity exception appears to be the right approach, which, if taken from the outset, could have saved a lot of confusion and uncertainty.

\section{A Reprieve for Contract?}

The analysis thus far has worked from the common assumption shared by all the Justices in INS, namely, that the common law framework of property, contract, and tort, as enforced by the action against mducement of breach of contract, cannot give the AP the injunctive reinedy it sought. But there is some difficulty in deciding whether this assumption would hold if the AP had adopted the most aggressive contractual strategy available.

Take, by way of counterexample, the following modification of the basic pattern: When the AP posts its news dispatches on the bulletin boards, it does so under a broad statement that says: "These bulletins are posted for the sole benefit of our subscribing coinpanies. No other person who reads this information is entitled to use or to transfer it to any other person for commercial reproduction."86 Similarly, when the AP sends its bulletins to its eastern papers, they all publish it under legends that proclaim that "the news contained herein is for the sole benefit of our subscribers and may not be reproduced for commercial use without the express written consent of the AP." Here there is no question that the INS, as a professional gatherer of news, could not claim that it took the news free of the restriction because it lacked notice of its contents or purpose. The ouly question is whether the restriction in question is one that would bimd persons taking the information with knowledge of the restriction.

${ }^{86}$ A parallel to the limitations on the broadcasts of the Chicago Cubs' games is evident. Whenever Steve Stone, the Cubs' excellent color man, informs viewers that "any use or rebroadcast of the descriptions or accounts of this game without the express written consent of the Cubs is definitely prohibited," the accent is on the "definitely," so we know that he means business, as do the Cubs. 
Why not? The case is surely one that differs vastly from a similar declaration that says "all persons who use the public highways do so on notice from the defendant that he will be driving his car in a reckless and irresponsible fashion," or from the case where the owner of land tells his neighbor "build your house at your own risk because I'm about to blast on my land." The difference is that in these last two cases, there is in place a well-designed system of property rights that allows a person to use the road and to have the protection of the tort law, or to use her land and have the protection of the tort law. What the defendant seeks to do in each imstance is to force the plaintiff to choose between two entitlements, each of which is fully protected. These "duress of goods" cases are like choosing between your money and your life when you are entitled to have both. ${ }^{87}$

But the cases are distimguishable. Although notice functions sometimes to defeat rights, in other contexts it functions to preserve them. The notice given in the above hypothetical about newspapers falls into this second class. It serves a useful social function, just as it does when strangers to the title receive notice that the bailee does not own property, and just as it does when a well-run recordation system affords notice to prospective purchasers of land. The recipient of the information had no right to get the information before it was placed on the bulletm boards or in the newspapers, and now he is told definitively that he can receive it only if he takes it subject to conditions. The conditions themselves hardly can be regarded as exploitative given that they prevent the type of degenerative social equilibrium that Judge Grosscup described so vividly. ${ }^{88}$

One simple way of looking at INS is as a question of what default terms of the contract should be imposed when the information is posted and published without the appropriate disclaimers. Because the express restriction works well, why not imply it as a matter of course and leave it to the AP to remove it if it so chooses? Or why not at least state that the restriction, if announced, would be respected

87 For my views, see Richard A. Epstein, Unconscionability: A Critical Reappraisal, 18 J.L. \& Econ. 293 (1975). Roughly analogous is the choice to which a landowner is put when the government gives notice of possible future plans to condemn the property in order to limit the development of property rights without compensation, a strategy $I$ have attacked on constitutional grounds in Richard A. Epstein, Takings: Private Property and the Power of Eminent Domain 77-80 (1985).

88 See supra text accompanying note 28 . 
and enforced as against direct competitors ${ }^{89}$ under the Christie principle? This contract approach would avoid some of the odd features of the quasi-property analysis to which Pitney resorts. Intelligent contracting with default notice rules would create the saine outcome that he achieved: using the inforination imphies acceptance of the contract subject to the conditions created, much like use of the immortal carbohic smoke ball with notice of the promise to pay created a contract without a fornal return acceptance. ${ }^{90}$

Yet here, too, the contract analysis cannot be pushed too far, at least if we recognize any antitrust-like limitations on freedom of contract. Suppose, for exainple, that the information in the newspaper is published with a warning: "Any person who uses the information acquired in this paper in order to inake its own busmess plans shall remit to this paper a sum equal to one percent of the profits inade from such a venture." Could anyone enforce a clause of this sort? At one level, the answer is that the wrong question is being asked. The right inquiry is whether any newspaper would seek to impose that clause in question, knowing that it would be subject to a torrent of abuse for deviatimg from the custoinary rules on the matter and to massive defections to other publications that still are willing to hive by the traditional rules.

But it is risky to rely too inuch on the "it won't happen so why worry about the question" analysis, for surely there are other cases in which this argument loses its punch. Board of Trade v. Dow Jones \& Co. ${ }^{91}$ is such a case. The Dow Jones Coinpany publishes its fainous Dow Jones average on a daily basis. If it included in its publication a statement that said "no recipient of the information may use it to create a stock index future contract," it would be able to preserve its

89 There are more serious problems when the information is used in a follow-on sense, and in that context, the notice of an intent to exclude seems to make sense as a transaction costminimization device, given that there is a single producer of the information and a large number of possible users who would find it costly to inquire on their own initiative.

90 See Carlill v. Carbolic Smoke Ball Co., 1 Q.B. 256 (1892) (treating the need to respond as having been waived by the offeror). Here there is this difference: the notice inposes restrictions that become part of the offer that is accepted, or, in the alternative, limits the class of persons to whom the offer (or transfer) of information is made, so that it can no longer be described as an offer to all the world. It is an offer only to the parties who are willing to abide by the conditions on use. For an exhaustive account of the case, see A.W.B. Simpson, Quackery and Contract Law: The Case of the Carbolic Smoke Ball, 14 J. Legal Stud. 345 (1985).

91456 N.E.2d 84 (IIl. 1983). 
traditional market, for the vast bulk of persons who use the index do so for other purposes; indeed, the restriction would exclude no use tolerated under the status quo ante. The question of whether a contractual clause of this sort should be enforceable raises the saine general question that the follow-on cases after INS present, namely, does the quasi-property right in news extend to controversies over news (which has a very short useful life) between non-competing firms?

In part, Pitney anticipated this problem. Although he said in very broad terms that the property right in news was created to insure that the INS could not appropriate the labor, skill, and money of the AP by "endeavoring to reap where it has not sown," 92 he was very careful to hem im that broad statement by drawing the distinction between "the right of the purchaser of a single newspaper to spread knowledge of its contents gratuitously" and the practice of the INS to sell that same knowledge "in competition with" the defendant. ${ }^{93} \mathrm{He}$ was doubtless well-aware of the fact that all sorts of people use information they read and would not have questioned that one of the essential conditions of hiving in a free and prosperous society is the freedom to use information (if not grain) sown by others. ${ }^{94}$ The creation of private property rights in information would allow large numbers of persons to block the use of valuable information by others. In light of that obvious peril, it would be a giant mistake to assume that the only objective of the law in the area of property rights is to prevent free riding by others. Some considerable degree of free riding is necessary to avoid the endless problems of hold-out and blockade.

Nonetheless, although Pitney was conscious of the limitations of the reap-and-sow maxim, his identification of the two polar situations-direct competition and casual use--skipped over the situation in Dow Jones, where the defendant makes follow-on use of the plaintiff's index for commercial gain in a market different from (if related

92 INS, 248 U.S. at 239.

93 Id.

94 As Professor Baird has written on this point:

That information once published should be presumptively free for all to use is a commonplace of intellectual property law. As Benjamin Kaplan has observed, "if man has any 'natural' rights, not the least must be a right to imitate his fellows, and thus to reap where he has not sown. Education, after all, proceeds from a kind of mimicry, and 'progress,' if it is not entirely an illusion, depends on generous indulgence of copying."

Baird, supra note 45, at 411 (quoting Benjamin Kaplan, An Unhurried View of Copyright 2 (1966)). 
to) that in which the plaintiff has earned its keep.95 In working through this intermediate case, it is far froin clear whether Dow Jones should receive the property protection that it seeks, even if it publishes its index witlı an explicit contractual prohibition against any future commercial use by a rival. In this case, arguments about property, custom, and contract tend to blend into a seamless but indistimct web.

First, unlike INS, there is no set of reciprocal interactions in Dow Jones that allows for the generation of any useful set of customary norms. Within the INS context itself, there is good reason to beheve that tlie appropriation of the stories by the rival will lead to the destruction of tlie market and that both parties adhere to the norm to avoid the terrible consequences that otherwise would follow. ${ }^{96}$ Pitney could have followed the Hayekian approach and decided the case on grounds of custom alone. That resolution surely is not possible im Dow Jones. There, sliort of legal protection, Dow Jones can do nothing to retaliate against a party that uses its average as a basis for a trading index because the parties stand in a fundainentally asymmetrical relationship to eacll other. Consequently, in Dow Jones, there would not have been a stable custoin on which to fashion a legal rule.

Second, by the same token, the social losses generated by not creating the property right on follow-on commercial uses seem fairly small, but, lowever small, these losses are not zero. Everyone knows that unanticipated benefits are wortl liaving at least to soine degree. Dow Jones, which had sufficient incentive to produce the average before, still lias that incentive because there is no direct coinpetition; there is, therefore, nothing about the creation of this novel futures contract that diminisles the gains that Dow Jones gets from producing its index. The ouly question is whetler it will gain some form of a windfall profit from a use that it had not anticipated at the time it first establislied its index. Denying it that right will reduce, at the margin, the incentive for Dow Jones to create its index in the first place, but the effect, ex ante, is apt to be very sinall because there is a long time delay between the time that the index was imvented and the time that its secondary use became feasible. In this setting, creating the small extra incentive to produce the index would mean that subsequent

95 Dow Jones, 456 N.E.2d at 86.

96 See supra text accompanying note 38 . 
innovators in related markets have to transact with Dow Jones, thereby creatimg high transaction costs and the risk of monopoly in some new product market.

Third, on the other side, it may well be that some negative "halo effect" will reduce the value of the Dow Jones index in its primary market, so that it will be left worse off if others can trade on its name. In what has to be regarded as an exceedingly close case, the Illinois Supreme Court in Dow Jones gave the property right in the Dow Jones futures contract to the company and thus barred the Board of Trade from trading its new index, noting that other imdices were available for trading. ${ }^{97}$ In essence, it decided that Dow Jones should be granted a property right because the monopoly risk is sinall. It may well have been influenced by the fact that Dow Jones refused to take hard cash for a hicense to use the name, ${ }^{98}$ which could be interpreted as evidence that Dow Jones did value the exclusive use highly and feared the negative halo effect.

In sum, cases like Dow Jones present a quandary for modern legal theory. There is no clear custom bearing on the formation of property rights, and no analytical approach that fills the gap. All that one can say is that we are fortunate indeed that the breakdown in legal theory coines at the point where the social consequences of alternative legal regimes are so closely balanced.

\section{The Role of Custom in Defining Property Rights}

Having examined the theoretical debate concerning the origin of property rights, the INS decision, and subsequent cases, we return to the question with which this Article began: What is the relationship of custom, law, and property? As the discussion thus far indicates, the INS decision and the cases following it reached results consistent with the custom of the news-gathermg industry, although they did not purport to derive their rules froin custoin. This congruence raises two conceptual probleins that require brief comment.

\section{A. Custom or Cost/Benefit Analysis: A Reprise}

The first is the question of technique: In dealing with the creation and recognition of property rights, should courts or legislatures refer

97 Dow Jones, 456 N.E.2d at 89-90.

98 See id. 
to custom or should they invoke general principles of positive law? Where they do the former, their task is essentially reflective, to find out the normative rules on which parties organize their social interaction. ${ }^{99}$ INS comes out the way it does because all parties to the industry acknowledged the basic property rights in news and the "tip" exception to it.

The opposite view, which asks judges and legislators to make positive law on property, requires them to confront first principles more directly. ${ }^{100}$ Although they may and will make an oceasional bow to the sovereign power of natural law, typically those bland pronouncements (which can, depending on the predisposition of the lawmaker, support either $A$ 's natural right to use or $B$ 's to exclude) will dissolve into a closer examination of the advantages and disadvantages of alternative legal rules, measured in terms of the total social satisfaction they generate. Judges and legislatures will act, therefore, as some imprecise form of social inaximizers and imventors, as did Pitney in predicting the decline of the news agencies if pirating were allowed.

There is peril in both these courses of action. To use the social utilitarian calculus is a risky thing, and the failure to take mto account certain relevant effects may lead to the adoption of the wrong legal rule. Indeed, the power of Hayek's own formal and rational analysis of legal norms rests in his compelling demonstration that customary rules and practices do work well, even if for reasons that the parties governed by those practices often do not understand and cannot fully articulate. In advocating rehance on custom instead of abstract reasoning in creating property rights, Hayek is the antithesis of the Socratic philosopher. Nonetheless, Hayek has made rational argument, of the type he is suspicious of, for relying on custoinary rules. $^{101}$ But when all is said and done, there still are cases where custom will fail as well, as the above discussion of Dow Jones reveals. ${ }^{102}$

As a result, the relative desirability of the two methodologies depends upon the comparative magnitude of their imperfections. In a world in which analysts were perfectly skilled in what they do, custoin could be dispensed with as a way station along the road to the

\footnotetext{
99 See supra text accompanying note 3 .

100 See supra text accompanying notes 1-2.

101 See, e.g., Gray, supra note 8.

102 See supra text accompanying notes 91-98.
} 
optimal collective delineation of property rights. As long as lawmakers are plagued with imperfect knowledge, however, the institutional dominance of analytical methods always will remain contestable. The best that can be said is that custom is deep, and works well in narrow domains, while cost/benefit analysis has greater range but weaker rehiability.

Accordingly, custom should be followed in those cases in which there are repeat and reciprocal interactions between the same parties, for then their incentives to reach the correct rule are exceedingly powerful. Because the parties operate perforce under a veil of ignorance, they will have every incentive incrementally to find the best set of accommodations to advance their joint welfare. So long as general constraints, such as the credible threat of retaliation for opportunistic conduct, are imposed upon future behavior, the only way that the individual can inaximize his own self-mterest is to seek the rule that advances the interest of the group as a whole. In a word, custom works well for direct competition, but not so well for follow-on cases.

In those domains where custom is weak, however, some explicit cost/benefit calculation has to be made. Here, the more lawmakers know about how individual rationality can either advance or subvert collective welfare, the better able they will be to pick that rule that works in the long run. It would be a mistake, now that the genie of transaction cost analysis is out of the bottle, to assume that we should spurn basic knowledge of how legal systenus and institutions work because lawmakers might misapply that knowledge. Better it is to array the full set of relevant considerations (imcluding those that relate to the limitations of knowledge) in support of the optimal legal rule. In so doing, freedom of contract between consenting parties and limited government comes out quite well, just as Hayek beheved. If custom had umiversal domains and if analysts had unerring imtellectual power, the two would agree on all outcomes, just as they do on the narrow issue of direct competition presented in INS. But im an imperfect world, it cannot be said that methods of rational deduction are necessarily inferior to custonuary methods. There is some division of their relative attractiveness along the lines noted above, which is why the tension of methodologies in the law shall persist over time. 


\section{B. From Industry to Government}

The second point concerns the extent to which one can generalize from the einergence of customary practices within an industry to the emergence of customary rules that govern the operation of societies writ large. Even if one concludes, as seems proper, that custoinary norms could have decided INS, it does not follow that custom lays the groundwork for society at large. ${ }^{103}$ Indeed, one conspicuous counterexample to the dominance of customary norms is The Federalist No. 1, where Alexander Hamilton notes expressly that the question of governance reduces to the "question, whether societies of men are really capable or not of establishing good government from reflection and choice, or whether they are forever destined to depend for their political constitutions on accident and force."104 And our original Constitution could not have been designed by custom, even if it has been radically undermined by judicial decisions. To be sure, custom still has an enormous attractiveness to the extent that the customary rules are those identified by Hume a long time ago: protect property from aggression and insure the enforcement of contracts between parties. ${ }^{105}$ Even where customary rules do have broad application, it cannot be assumed as a matter of course that their enforcement can be left to customary sanctions. INS agam hints at the lesson: the mutual limitations on pirating news did not survive the Britislı and French ban of the INS.

More generally, decentralized customs may be generated without legal interference and control, but legal force may be necessary to maintain them against systematic defection. Indeed, the entire debate over whetlier some level of coercion is required first to form, and then to maintain, the state rests im part upon the cominon (dare one say customary) perception that purely private agreements will break down in the face of opportunistic behavior. That argument is not overconie by slowing that customs in particular trades or imdustries have proved stable without government support. In many instances, these custoins were able to form only because the government had supplied industry with the essential protection against external

103 Hayek, therefore, may be fairly charged with a bit of excessive optimism in the assumption that the spontaneous order that emerges in given trades can emerge for entire societies. See sources cited supra note 8 for Hayek on spontaneous order.

104 See The Federalist No. 1, at 33 (Alexander Hamilton) (Clinton Rossiter ed., 1961).

105 See Huine, supra note 7, at 501-25. 
aggression that it needed to survive and flourish. The role of custom as a source of incremental improvement where order is secured by collective government does not imply that custorn itself can be the source of the imitial political order that allows those incrennental improvements to emerge. In other words, what works as a protected inechanisin within a limited sphere may not work as an improtected one in an unbounded domain.

\section{CONCLUSION}

Economists long have said that there are distinct perils in trying to draw general equilibrium conclusions from partial equilibrium models. Lawyers who look at the role of custoin cannot afford to forget that lesson, whether dealing with the origins of intellectual property rights, or, for that inatter, anything else. They also should learn that customs and imdustry practices within partial equilibriuin settings often have a durability that our own techniques of rational analysis can achieve only miperfectly. All these lessons are, I think, implicit in INS, which is why it will remain one of the enduring inonuments of the common law. 